\title{
Covid-19: To meter er kanskje ikke nok
}

\section{Dråper, dråpekjerner og aerosoler kan smitte over større avstander enn antatt. Hvis vi skal få kontroll over pandemien, bør alle smitteveiene avbrytes.}

Jörn Klein

Professor i mikrobiologi og smittevern

Institutt for sykepleie- og helsevitenskap, Universitetet i Sørøst-Norge

\begin{tabular}{|l|l|}
\hline Smitte Hms Covid-19 SARS-CoV-2 \\
\hline
\end{tabular}

Sykepleien 2021109 (83362) (e-83362)

DOI: 10.4220/Sykepleiens.2021.83362

\section{Hovedbudskap}

De fleste av oss tilbringer mye tid innendørs, der vi deler luften vi puster. Den utåndede luften blandes med resten av romluften og blir delvis innåndet igjen av de tilstedeværende. Hva er da betydningen av dråper og aerosoler som ikke overholder «enmetersgrensen»?

Covid-19-pandemien, forårsaket av severe acute respiratory syndrome coronavirus 2 (SARS-CoV-2) har vært assosiert med infeksjoner og dødsfall blant helsepersonell, beboere på sykehjem og pasienter.

Det har vært motstridende anbefalinger om bruk av munnbind, ventilasjon og smitteverntiltak og uenighet om rollen dråper og aerosoler spiller i overføringen av koronaviruset. Mange diskusjoner om smitteverntiltak minner om situasjonen for rundt 30 år siden da man diskuterte luftsmitte og smitteverntiltak for tuberkulose (1, 2). 
Denne oversikten er ikke en gjennomgang av litteraturen om bruk av munnbind, som flere allerede har gjort (3-6), men den er et fors $\varnothing \mathrm{k}$ på å belyse de medisinske og fysikalske grunnlagene for smitte via dråpene og aerosoler.

\section{Hvilken betydning har dråper og aerosoler?}

Hovedsmitteveien for SARS-CoV-2 er respiratorisk opptak av virusholdige væskepartikler som oppstår når man puster, snakker, hoster og nyser. Siden SARS-CoV-2 kan overføres noen dager før symptomene oppstår, vil presymptomatisk smitte bidra vesentlig til den totale covid-19-pandemien (7).

Oppfatningen om at dråpesmitte bare forekommer innen en til to meter, er basert på gamle påstander og eksperimenter. I 1910 publiserte Charles Chapin en bok som skulle bli førende innen smittevern. I The sources and modes of infection (8) prøver han å forklare hvorfor avstand reduserer smitte.

I kapitlet om luftbåren infeksjon konkluderer han med at man ikke kan utelukke smitte via aerosoler, men at det vil være helsepedagogisk vanskelig å formidle. Senere ble det et dogme innen smittevern, en påstand som ingen etterprøvde.

\section{$\equiv$ «Oppfatningen om at dråpesmitte bare forekommer innen en til to meter, er basert på gamle påstander og eksperimenter.»}

Andre studier av hvordan dråper slippes ut under tale, hoste eller nysing, begynte på 180o-tallet, der forskere vanligvis samlet prøver på agarskåler (9). I 1897 foreslo Flugge en til to meter som trygg avstand basert på slike eksperimenter (10).

På 1940-tallet ble fotografisk dokumentasjon av dråpespredning mulig (11). Disse tidlige studiene hadde begrenset nøyaktighet, spesielt for lengre avstander. Likevel danner disse resultatene fortsatt grunnlaget for avstandsregelen om en til to meter. 
Ifølge nyere funn kan dråper transporteres opptil åtte meter (12). I motsetning til aerosoler faller imidlertid større dråper til slutt på overflater og blir ikke i luften i flere timer, noe som kan ha en avgjørende innflytelse på eksponeringens varighet. Derfor er det ikke alltid tilstrekkelig å holde en avstand på to meter for å unngå en dråpeinfeksjon, for eksempel ved ukontrollert hoste eller nysing og ved turbulente luftstrømmer (12).

Større dråper og dråpekjerner spiller derfor en rolle også ut over «enmetersgrensen». I et miljø der luften «står stille», kan de mange små dråpene eller dråpekjernene som slippes ut når man snakker, tenkes som en usynlig «sky» som bare sakte legger seg (13).

Hvorvidt og hvor raskt dråper og aerosoler synker eller blir værende i luften, avhenger av størrelsen på partiklene og en rekke andre faktorer, inkludert temperatur, fuktighet (14) og luftbevegelse.

\section{Partikkelstørrelsen og antallet dråper påvirker}

Avhengig av partikkelstørrelse skilles det mellom store dråper (større enn 5-10 $\mu \mathrm{m}$ ) og mindre dråper eller dråpekjerner (15). Overgangen er flytende; såkalte dråpekjerner kan oppstå fra dråper når de tørker ut i luften (16).

Når dråpene har forlatt nesen eller munnen, fordamper vanninnholdet veldig raskt. Det som gjenstår, er de faste komponentene i form av mindre partikler som synker saktere. Ved $1 \mu \mathrm{m}$ store dråper fordamper vannet på noen få millisekunder, mens $100 \mu \mathrm{m}$ store dråper trenger nesten ett minutt på å fordampe vannet (16).

\section{$\equiv$ ¿Mindre dråper holder seg betydelig lenger i luften.»}

Mindre dråper holder seg betydelig lenger i luften (13). Når det gjelder større dråper, spiller ikke dehydrering noen rolle de er så tunge at de raskt faller på gulvet. En dråpe på $500 \mu \mathrm{m}$ faller innen ett sekund fra en høyde på 1,6 meter. En liten dråpe $(10 \mu \mathrm{m})$ trenger ni minutter (17).

På grunn av den lave vekten til dråpekjerner kan de flyte i luften i lang tid (aerosol). Hvis dråpekjerner blir inhalert, når de til de nedre luftveiene $(14,18,19)$. 


\section{Hvordan fungerer luftveiene?}

Aerosoler skilles ut når man puster og snakker, men enda mer når man skriker og synger. Hoste og nysing gir betydelig flere dråper $(20,21)$. Her er det viktig å minne om luftveienes fysiologi:

- Luftveiene er dekket med et væskelag (lining fluid), som er mellom 5 og $100 \mu$ m tykk. Luftstrømmens bevegelser produserer dråper. Ved maksimal dyp utånding blir antallet dråper opptil 18 ganger høyere (16).

- Dråpene som dannes i bronkiolene, er $\leq 1$ mikrometer i størrelse. Dråper som dannes i strupehodeområdet, er allerede større, og dråper som oppstå i munnhulen, er $\geq 20$ $\mu \mathrm{m}$ i størrelse (16).

- Under vanlig tale avgir en voksen person mellom 1000 og 10 ooo dråper per sekund (13), hvorav 95 prosent er $<1 \mu \mathrm{m}$ $(17,22)$. Antallet frigitte dråper $\varnothing$ ker med talevolumet (13).

- Et hostekast produserer mellom 1000 og 10000 partikler med en størrelse på 0,5-30 mikrometer (hovedsakelig partikler $<2 \mu \mathrm{m})(13,16)$.

- Nysing genererer omtrent 1 million partikler mellom 0,5 og $16 \mu \mathrm{m}$ i størrelse og resulterer i en «dråpeaerosolsky» som kan være rundt 7-8 meter i omfang $(22,23)$.

- Når den relative luftfuktigheten er lav, kan flere dråpekjerner forbli lenger i luften, noe som gjør det mer sannsynlig at de blir inhalert (24).

\section{Slik spres dråpene}

Ved dråpesmitte treffer dråpene typisk kontaktpersoner som en spray i фyne, nese og munn (12) og blir «fanget» der av slimhinnene (14). Denne smitteveien blir ansett som den viktigste for SARS-CoV-2.

De små dråpekjernene kan flyte i luften i lang tid (aerosol), distribuere seg i lukkede rom og sveve over ti meter (14). Derfor er det ut over tometersgrensen snakk om en «overføring via aerosoler (16).

\section{Hva påvirker infeksjonsrisikoen?}

Infeksjonsrisikoen er resultatet av et komplekst forhold mellom verten og et patogen. De fleste faktorene som påvirker infeksjonen og sykdommens alvorlighetsgrad, er relatert til verten. Egenskapene til mikroben er virulens, antall, eksponeringsvei og eksponeringstid (25). 
Virulensen er ikke mulig å endre. Så lenge en effektiv vaksine ikke er tilgjengelig, kan immunforsvaret bare påvirkes i svært begrenset grad. Realistisk sett kan vi bare påvirke eksponeringen og dermed antallet patogener, altså smittedosen, for å unngå SARS-CoV-2-infeksjon.

\section{Flere faktorer påvirker eksponeringen}

Hvis minimumsavstanden opprettholdes, er det lav sannsynlighet for smitte utend $\varnothing$ rs på grunn av luftbevegelsen og UV-strålingen (26).

Situasjonen er annerledes innend $\varnothing$ rs: SARS-CoV-2 var i stand til å overleve i en eksperimentell studie i aerosoler i minst tre timer (27). En rekke risikofaktorer kan $\varnothing$ ke sannsynligheten for SARS-CoV-2-smitte gjennom mindre - og muligens større - dråper over en avstand på mer enn to meter.

\section{三 «SARS-CoV-2 var i stand til å overleve i en eksperimentell studie i aerosoler i minst tre timer.»}

Hvis rommet er dårlig ventilert og en eller flere personer som frigjør smittsomme dråper ut i romluften, er til stede i en viss periode, $\varnothing$ ker eksponeringen. Atferden påvirker frigjøringen av små dråper (16).

I tillegg spiller inneklimaet en viktig rolle, siden det kan oppstå en akkumulasjon av partikler. For eksempel har svært mange skoler i Norge et dårlig inneklima på grunn av manglende vedlikehold (28). Forfattere beskriver blant annet en høy finst $\varnothing$ vforurensning i skolebygg, og finst $\varnothing \mathrm{v}$ kan $\varnothing \mathrm{ke}$ rekkevidden til aerosoler (29).

Spesielt på kalde vinterdager synker den relative fuktigheten innendørs, noe som kan resultere i tørre slimhinner, som da igjen kan svekke immunforsvaret (30).

\section{Hva er smittedosen og inngangsporten?}

For andre smittsomme sykdommer er det kjent at en viss minimumsmengde av patogener må absorberes i kroppen før en infeksjon kan oppstå. Denne smittedosen er veldig lav for noen patogener, for eksempel norovirus. Den smittsomme dosen for SARS-CoV-2 er foreløpig ukjent. Når det gjelder SARS-CoV-1, anslås det til noen få hundre viruspartikler. 


\title{
«Det kan antas at langvarig eksponering fører til en akkumulering av små mengder virus, slik at smittedosen oppnås.»
}

Direkte kontakt ansikt-til-ansikt fører til at den nødvendige smittedosen absorberes mye raskere enn hvis tilstrekkelig avstand opprettholdes, eller hvis en stor del av dråpene eller aerosolene holdes borte av et passende munnbind. Det kan antas at langvarig eksponering fører til en akkumulering av små mengder virus, slik at smittedosen oppnås (17).

Generelt fører opptak av respiratoriske patogener i lungene til et mer alvorlig klinisk bilde (31). Partikler $\leq 10 \mu \mathrm{m}$ kan komme inn i nedre luftveier (ved $<1-3 \mu$ m direkte i alveolene).

Partikler $>10 \mu \mathrm{m}$ når bare de $\varnothing v r e$ luftveiene ifølge gjeldende oppfatning $(12,31)$. Smitte via aerosoler er forbundet med mer alvorlige symptomer ved influensa (15).

\section{Ventilasjon og munnbind er viktig}

Inntil mer detaljerte vitenskapelige funn tillater et mer differensiert syn, bør både dråper og aerosoler tas i betraktning når man bestemmer smitteverntiltak for å unngå SARS-CoV-2-infeksjon.

Ventilasjon kan effektivt redusere konsentrasjonen av smittsomme aerosoler innendørs. Derimot er det ennå ikke avklart hvor viktig ventilasjon er for å unngå typiske dråpeinfeksjoner. Også et vanlig munnbind er mest sannsynlig tilstrekkelig for å redusere risikoen for smitte via aerosoler under mange omstendigheter.

For SARS-CoV-2 er smitte via dråpekjernene i luften ut over to meter trolig ikke hovedveien, men en «opportunistisk», det vil si ytterligere, smittevei (32). For å kontrollere pandemien bør imidlertid alle smitteveiene avbrytes (14).

\begin{abstract}
ALARA er et akronym for «As Low As Reasonably Achievable», på norsk «så lavt som rimelig oppnåelig». Det beskriver et prinsipp om strålevern.
\end{abstract}

Når det gjelder ioniserende stråling, krever ALARA-prinsippet at mennesker, dyr og materiale utsettes for så lave nivåer av stråling (til og med under grenseverdier) som det er praktisk mulig å gjennomføre, og ved å avveie fordeler og ulemper. 
I analogi med føre var-tanken innen strålevern bør sannsynligheten for eksponering for SARS-CoV-2, antallet eksponerte personer og den individuelle dosen patogener som påvirker en person, holdes så lavt som det er rimelig oppnåelig.

\section{Referanser}

1. Sepkowitz KA. How contagious is tuberculosis? Clin Infect Dis. 1996;23(5):954-62.

2. Fennelly KP. Personal respiratory protection against Mycobacterium tuberculosis. Clin Chest Med. 1997;18(1):1-17.

3. Li Y, Liang M, Gao L, Ahmed MA, Uy JP, Cheng C et al. Face masks to prevent transmission of COVID-19: a systematic review and meta-analysis. Am J Infect Control. 2020.

4. Chaabna K, Doraiswamy S, Mamtani R, Cheema S. Facemask use in community settings to prevent respiratory infection transmission: a rapid review and meta-analysis. Int $\mathrm{J}$ Infect Dis. 2020.

5. Chu DK, Akl EA, Duda S, Solo K, Yaacoub S, Schunemann HJ et al. Physical distancing, face masks, and eye protection to prevent person-to-person transmission of SARS-CoV-2 and COVID-19: a systematic review and meta-analysis. Lancet. 2020;395(10242):1973-87.

6. Brainard J, Jones NR, Lake IR, Hooper L, Hunter PR. Community use of face masks and similar barriers to prevent respiratory illness such as COVID-19: a rapid scoping review. Euro Surveill. 2020;25(49):2000725.

7. Buitrago-Garcia D, Egli-Gany D, Counotte MJ, Hossmann $\mathrm{S}$, Imeri H, Ipekci AM et al. Occurrence and transmission potential of asymptomatic and presymptomatic SARS-CoV-2 infections: a living systematic review and meta-analysis. PLoS Med. 2020;17(9):e1003346.

8. Chapin CV. The sources and modes of infection. 1. utg. New York: J. Wiley \& sons; 1910.

9. Papineni RS, Rosenthal FS. The size distribution of droplets in the exhaled breath of healthy human subjects. Journal of Aerosol Medicine. 1997;10(2):105-16. 
10. Flügge C. Ueber luftinfection. Zeitschrift für Hygiene und Infektionskrankheiten. 1897;25(1):179-224.

11. Turner CE, Jennison MW, Edgerton HE. Public health applications of high-speed photography. Am J Public Health Nations Health. 1941;31(4):319-24.

12. Sommerstein R, Fux CA, Vuichard-Gysin D, Abbas M, Marschall J, Balmelli C et al. Risk of SARS-CoV-2 transmission by aerosols, the rational use of masks, and protection of healthcare workers from COVID-19. Antimicrob Resist Infect Control. 2020;9(1):100.

13. Stadnytskyi V, Bax CE, Bax A, Anfinrud P. The airborne lifetime of small speech droplets and their potential importance in SARS-CoV-2 transmission. Proc Natl Acad Sci USA. 2020;117(22):11875-7.

14. Morawska L, Cao J. Airborne transmission of SARS-CoV-2: the world should face the reality. Environ Int.

2020;139:105730.

15. Tellier R, Li Y, Cowling BJ, Tang JW. Recognition of aerosol transmission of infectious agents: a commentary. BMC Infect Dis. 2019;19(1):101.

16. Wei J, Li Y. Airborne spread of infectious agents in the indoor environment. Am J Infect Control. 2016;44(9 Suppl):S1O2-8.

17. Somsen GA, van Rijn C, Kooij S, Bem RA, Bonn D. Small droplet aerosols in poorly ventilated spaces and SARS-CoV-2 transmission. Lancet Respir Med. 2020;8(7):658-9.

18. Buonanno G, Morawska L, Stabile L. Quantitative assessment of the risk of airborne transmission of SARS-CoV2 infection: Prospective and retrospective applications.

Environ Int. 2020;145:106112.

19. Verdens helseorganisasjon (WHO). Transmission of SARS-CoV-2: implications for infection prevention precautions. Verdens helseorganisasjon; 2020. Tilgjengelig fra: https://www.who.int/newsroom/commentaries/detail/transmission-of-sars-cov-2implications-for-infection-prevention-precautions (nedlastet 26.01.2021). 
20. Wilson NM, Norton A, Young FP, Collins DW. Airborne transmission of severe acute respiratory syndrome coronavirus-2 to healthcare workers: a narrative review. Anaesthesia. 2020;75(8):1086-95.

21. Gralton J, Tovey E, McLaws ML, Rawlinson WD. The role of particle size in aerosolised pathogen transmission: a review. J Infect. 2011;62(1):1-13.

22. Romano-Bertrand S, Aho-Glele LS, Grandbastien B, Gehanno JF, Lepelletier D. Sustainability of SARS-CoV-2 in aerosols: should we worry about airborne transmission? J Hosp Infect. 2020;105(4):601-3.

23. Bourouiba L. Turbulent gas clouds and respiratory pathogen emissions: potential implications for reducing transmission of COVID-19. JAMA. 2020;323(18):1837-8.

24. Xie X, Li Y, Chwang AT, Ho PL, Seto WH. How far droplets can move in indoor environments - revisiting the Wells evaporation-falling curve. Indoor Air. 2007;17(3):211-25.

25. Public Health Agency of Canada. Pathogen risk assessment. Canada: Government of Canada; 2018.

26. Sagripanti JL, Lytle CD. Estimated inactivation of coronaviruses by solar radiation with special reference to COVID-19. Photochem Photobiol. 2020;96(4):731-7.

27. van Doremalen N, Bushmaker T, Morris DH, Holbrook MG, Gamble A, Williamson BN et al. Aerosol and surface stability of SARS-CoV-2 as compared with SARS-CoV-1. N Engl J Med. 2020;382(16):1564-7.

28. Becher R, Bjerke M, Martinsen F, Vrevik J. Inneklima i skoler og barnehager: helsemessig betydning for barn og unge. Oslo: Folkehelseinstituttet; 2016.

29. Ahlawat A, Wiedensohler A, Mishra SK. An overview on the role of relative humidity in airborne transmission of SARS-CoV-2 in indoor environments. Aerosol and Air Quality Research. 2020;20(9):1856-61.

30. Kudo E, Song E, Yockey LJ, Rakib T, Wong PW, Homer RJ et al. Low ambient humidity impairs barrier function and innate resistance against influenza infection. Proc Natl Acad Sci USA. 2019;116(22):10905-10. 
31. Thomas RJ. Particle size and pathogenicity in the respiratory tract. Virulence. 2013;4(8):847-58.

32. Klompas M, Baker MA, Rhee C. Airborne transmission of SARS-CoV-2: theoretical considerations and available evidence. JAMA. 2020;324(5):441-2. 